\title{
ANALISIS PENGEMBANGAN USAHA PRUKADES (PRODUK UNGGULAN DESA) MADULANG SAMPANG MELALUI GROWTH HACKING MARKETING STRATEGY
}

\author{
Moh. Syarif ${ }^{1}$, Musoffan ${ }^{2}$ \\ syarifozy45@gmail.com ${ }^{1}$, soffan.mechazhen@ @mail.com ${ }^{2}$ \\ STIE Bakti Bangsa Pamekasan
}

\begin{abstract}
ABSTRAK
Prukades (Produk Unggulan Desa) merupakan kemampuan suatu desa untuk menciptakan suatu produk yang bernilai, guna memanfaatkan sumber daya yang ada di desa, sehingga mendatangkan pendapatan bagi masyarakat maupun pemerintah desa.Setiap desa memiliki potensi-potensi yang dapat dikembangan secara nyata, namun tak semua desa mampu menciptakan produk unggulan yang ada di desanya. Desa madulang merupakan desa yang memiliki produk unggulan "Kripik Tette".Kripik ini berjenis kripik singkong yang diolah secara tradisional dengan memadukan kearifan setempat (local wisdom).Dalam perkembangannya banyak tantangan-tantangan yang harus dilalui oleh desa agar produk yang dihasilkannya mampu menembus pasaran dengan baik, sehingga berbagi upaya harus dilakukan.Permasalahan yang kerap kali ditemui dalam pengembangan produk unggulan desa tersebut adalah pengembangan pemasaran usaha.Sehingga penelitian ini sangat di harapakan agar pengembangan usaha produk unggulan desa yang berbasis local wisdom ini tetap berkembang dan harapannya mampu menembus pasar komoditi internasional.

Kata Kunci: Prukades, Strategi Pemasaran, Growth Hacking
\end{abstract}

\begin{abstract}
Prukades (Village Leading Product) is the ability of a village to create a valuable product, in order to utilize the existing resources in the village, so as to generate income for the community and village government. Each village has potentials that can be developed significantly, but not all villages are able to create superior products in their villages.Madulang village is a village that has a superior product "Kripik Tette". These chips are cassava chips traditionally processed by combining local wisdom. In its development there are many challenges that must be overcome by the village so that the products it produces are able to penetrate the market with good, so sharing efforts must be done. The problem that is often encountered in the development of the village's superior products is the development of business marketing. So this research is highly hoped for so that the development of village superior product businesses based on local wisdom will continue to grow and hopefully it will be able to penetrate the international commodity market.

Keywords: Prukades, Marketing Strategy, Growth Hacking
\end{abstract}




\section{PENDAHULUAN}

Undang-Undang Desa Nomor 6 Tahun 2014 memberikan stimulan yang sangat baik bagi desa agar menjadi mandiri dan sejahtera. Desa merupakan ujung tombak pelaksanaan pemerintahan dalam melaksanakan segala bentuk kebijakan yang telah dibuat oleh pemerintah, baik tingkat pusat, provinsi, maupun tingkat daerah. Segala bentuk usaha dan upaya harus dimaksimalkan oleh desa agar bisa mengeksplor potensipotensi yang bisa dikembangkan oleh desa salah satunya adalah pengembangan produk unggulan desa (Prukades). Desa Madulang adalah satu desa di Kecamatan Omben Kabupaten Sampang yang berbatasan langsung dengan Desa Proppo Kabupaten Pamekasan. Berada di desa perbatasan pada umumnya, sangat sulit di jangkau oleh pemerintah daerah maupun pusat, sehingga biasanya kemiskinan sangat banyak ditemukan di daerah perbatasan kota.

Desa Madulang merupakan salah satu desa dataran tinggi yang memiliki luas wilayah \pm 28.1935 Ha dengan bentangan area pertanian yang sangat luas. Mata pencaharian penduduk Desa Madulang adalah pertanian dengan hasil pertanian antara lain; padi, jagung, singkong, tembakau dan kacang-kacangan. Hasil produksi singkong Desa Madulang pada tahun 2018 mencapai 12.500 Ton/ha. Selain itu singkong hasil produksi Desa Madulang juga dikenal masyarakat luas dengan hasil rebusan singkong yang gurih dan nikmat. Sehingga dari potensi tersebut pemerintah Desa Madulang berinisiatif untuk membuat sebuah produk unggulan desa dari hasil olahan singkong. Pada ada tahun 2018 muncullah sebuah gagasan untuk membuat produk unggulan desa yang diberi Brand "Keripik Tette" modern dengan beraneka macam rasa.

Keripik tette adalah sebuah kripik singkong yang diolah, direbus dan ditumbuk hingga menjadi gepeng/pipih. Sehingga melalui proses penumbukan dengan menggunakan alat tradisonal batu, orang Madura menyebutnya di Tette. Keripik tette secara tradisional banyak dijumpai di pasaran berupa oalahan mentah yang masih perlu dijemur dan digoreng, biasanya keripik tette yang masih mentah tersebut banyak dijual dipasar-pasar tradisional dan UMKM/souvenir oleh-oleh khas Pulau Madura. Pada tahun 2018, Desa Madulang melalui Badan Usaha Milik Desa "BUMDesa Madulang Jaya" mencoba memodifikasi produk unggulan tersebut, yang awalnya masih dijual dalam kondisi masih mentah, kini diolah dan dijual dengan produksi siap konsumi dengan aneka varian rasa. Alhmadulillah, sudah banyak peminat dari kalangan 
masayarakat desa hingga luar jawa yang mulai berbondong-bondong untuk membeli produk Kripik Tette olahan tersebut. Seiring berjalannya waktu, produksi Kripik Tette olahan masih belum mencapai target masksimal hal ini masih terkendala pada sistem pemasarannya.

Oleh karena itu, permasalahan mendasar dalam penelitian ini adalah sistem pemasaran penjualan produk ungulan desa yang digunakan masih besifat tradisional dan monoton sehingga produksi yang dikembangkan pun masih tergolong rendah, alhasil pengembangan produk unggulan desa masih belum mencapai target penjualan yang baik sehingga penyerapan tenaga kerja serta peningkatan ekonomi masyarakat desa pun masih belum signifikan. Oleh karena ini tujuan dari penelitian ini akan mengkaji secara mendasar serta memberikan solusi strategi dalam sistem pemasaranproduk unggulan desa yang masih baru berkembang. penelitian ini, diharapakan dapat membantu proses pengembangan usaha produk unggulan desa melalui strategi pemasaran Growth Hacking agar usaha tersebut dapat berkembang dengan baik dan lambat laun mampu menyerap tenaga kerja masyarakat desasehingga dalam jangka panjang dapat meningkatkan perekonomian masyarakat desa, khususnya Desa Madulang.

\section{METODOLOGI PENELITIAN}

Jenis penelitian yang digunakan adalah jenis penelitian kualitatif denan pengamatan secara langsung (partisipan observation) yang datanya berasal dari wawancara, dokumen-dokumen yang bertujuan untuk menggambarkan realitas yang kompleks. Diawali dengan Identifikasi masalah dan potensi), melakukan Studi Literatur, mengindentifikasi dan menentukan variabel, m engidentifikasi dan menyusun alat observasi dan pengukuran, melakukan wawancara terkait dengan Strategi Pengembangan prukades melalui growth hacking, analisis data dan kesimpulan berikut alur pelaksanaan penelitian:

Gambar 3 alur metode penelitian

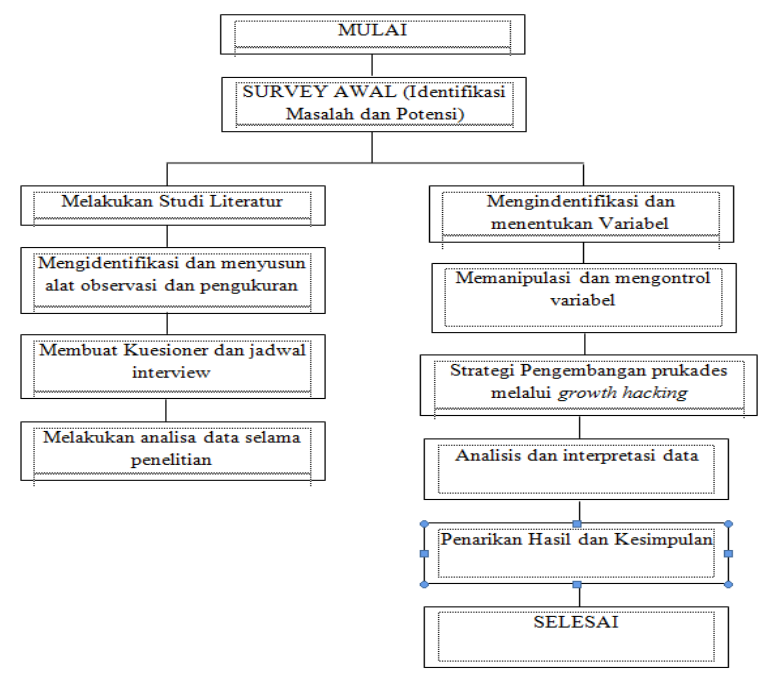




\section{HASIL DAN PEMBAHASAN}

\section{Konsep Pembangunan Ekonomi Desa Melalui Pendekatan Prukades}

Ekonomi masyarakat desa identik dengan kemiskinan dan kesenjangan. Pemberdayaan ekonomi masyarakat desa sangatlah dibutuhkan guna mengurangi tingkat kemiskinan dan kesnjangan melalui sisi pemberdayaan masyarakat desa. Pembangunan ekonomi desa merupakan proses pengelolaan suberdaya yang ada di desa yang dimotori oleh pemerintah desa beserta masayarakatnya sehingga membentuk pola kemitraan antara pemerintah daerah dengan sektor swasta untuk menciptakan suatu lapangan kerja baru dan merangsang perkembangan kegiatan ekonomi di desa.

Oleh karenanya melalui partisipasi masyarakat dengan memanfaatkan sumberdaya yang ada harus mampu menaksir potensi sumber-sumberdaya yang diperlukan untuk merancang dan membangun perekonomian desa. Dalam perencanaan pembangunan ekonomi desa mengarahkan penekanan terhadap kebijakan-kebijakan pembangunan yang didasarkan pada nilai karakteristik dan juga potensi sumberdaya manusia, sumberdaya alam, sumberdaya finansial dan serta sumberdaya dalam unsur kelembagaan.

Orientasi yang bersifat aktif dan partisipatif ini mampu menciptakan kesempatan kerja baru dan merangsang peningkatan kegiatan ekonomi. Menurut Sudarsono (2001), dinamika keunggulan daerah di masa mendatang ditandai dengan mempu tidaknya daerah dalam meraih peluang menghadapi kompetisi pasar bebas baik di tingkat regional maupun global. Berikut Beberapa langkah dan strategi agar desa dapat berkompetisi antara lain:

1. Menggalakkan program padat karya tunai sesuai Permendes nomor 13 tahun 2020 dengan memperbanyak tenaga kerja desa setempat sehingga dapat membuka peluang pertumbuhan ekonomi masyarakat di desa tersebut.

2. Pelayan yang prima yang diterapkan oleh pemerintah desa agar dapat dilirik oleh investor yang hendak ingin bergabung dalam upaya pembangunan desa.

3. Membuka jaringan seluas-luasnya guna mendapatkan informasi dalam kemajuan teknologi dan perkembangan desa menuju desa mandiri.

4. Memfasilitasi lembaga keuangan agar bersedia memberikan modal usaha bagi industri skala kecil dan menengah pada berbagai sektor unggulan desa, sehingga mereka dapat menjamin dan mempertahankan keberlangsungan usahanya. 
5. Berperan mentransportasikan ilmu pengetahuan dan teknologi terapan di berbagai sektor unggulan produk desa, agar proses produksi dapat mencapai efektifitas, efisiensi, dan ekonomis.

6. Mendorong agar para produsen mengembangkan jenis-jenis produk unggulan yang bersifat komplementer baik intern maupun antar region, memiliki nilai tambah dan menghasilkan manfaat ganda baik secara backwardlinkage dan forward linkage terhadap berbagai sektor, dengan demikian dapat memperkuat posisi daerah dari pengaruh fluktuasi ekonomi

7. Memposisikan birokrasi pemerintah desa cukup berperan sebagai katalisator, stimulator, dan regulator agar mekanisme pasar dapat bekerja secara sehat

8. Memprioritaskan program pembangunan infrastuktur yang dibutuhkan dalam rangka kemudahan aksebilitas usaha di bidang industri meliputi sarana transprtasi, komunikasi, energi, lokasi industri, sarana dan prasarana pelayanan umum yang baik serta situasi lingkungan yang sehat dan aman.

\section{Penerapan Elemen Growth Hacking Startegy Pada Produk Unggulan Kripik Tette}

\section{Madulang}

Pelaksanaan Kegiatan Pengembangan Prukades dalam hal ini yang adapun yang dilakukan antara lain:

\section{Survey}

Survey pada objek yang diteliti yaitu Desa Madulang. Desa Madulang merupakan salah satu desa yang berada di Kecamatan Omben Kabupaten Sampangyang terletak di bagian timur batas Kecamatan Omben yang berbatasan langsung dengan desa di Kecamatan Proppo Kabupaten Pamekasan. Desa Madulang terdiri dari 4 Dusun dengan luas wilayah sekitar $5.300 \mathrm{~km}^{2}$. Menurut jenis penggunaan tanahnya, luasan tersebut terinci sebagai berikut:

Tabel 1. Luas Tanah Menurut Penggunaan

\begin{tabular}{|c|l|c|}
\hline No & Jenis Penggunaan Tanah & Luas $(\mathrm{Ha})$ \\
\hline 1. & Pemukiman / Perumahan & 45.00 \\
\hline 2. & Sawah & 97 \\
\hline 3. & Tegal & 111 \\
\hline 4. & Hutan & 2.2 \\
\hline 5. & Lainnya & 10 \\
\hline
\end{tabular}

Sumber Data : Data Potensi Sosial Ekonomi Desa Tahun 2019 
Sebagian besar wilayah Desa Madulang adalah berupa dataran.Secara agraris tanah sawah juga relatif luas sebagai lahan penanaman untuk tanaman semusim. Ada beberapa komoditi yang banyak diusahakan oleh para petani di Desa Madulangyang dianggap sesuai dengan kondisi lahan yang ada, yaitu sebagai berikut:

Tabel 2. Komoditas Pertanian di Desa Madulang Tahun 2019

\begin{tabular}{|c|l|c|c|c|}
\hline No & Komoditas & $\begin{array}{c}\text { Luas Lahan } \\
\text { Panen } \\
\text { (Ha) }\end{array}$ & $\begin{array}{c}\text { Produk } \\
\text { si (kwt) }\end{array}$ & $\begin{array}{c}\text { Volume } \\
\text { (Kwt/Ha) }\end{array}$ \\
\hline 1. & Singkong & 150.00 & 65.15 & 153.00 \\
\hline 2. & Padi & 133.00 & $\begin{array}{c}51.2 \\
0\end{array}$ & 142.00 \\
\hline 3. & Jagung & 122.00 & $\begin{array}{c}48.2 \\
0\end{array}$ & 122.00 \\
\hline 4. & Kedelai & 50.00 & $\begin{array}{c}20.0 \\
0\end{array}$ & 52.00 \\
\hline 5. & Kacang Tanah & 97.00 & $\begin{array}{c}88.0 \\
0\end{array}$ & 77.00 \\
\hline 6. & Kacang Hijau & 0 & 0 & 0 \\
\hline
\end{tabular}

Sumber Data : Data Potensi Sosial Ekonomi Desa Tahun 2019

Dari data tabel diatas dapat disimpulkan bahwa sebagian besar luas lahan yang di Desa Madulang dialokasikan untuk penanaman singkong, sehingga produksi singkong di Desa Madulang merupakan komoditas tertinggi.Sebagian besar masayarakat Desa Madulang bertani singkong hanya untuk sebagai kebutuhan tambahan pangan saja, sisanya untuk dijual secara mentah ke pasar-pasar besar yang ada di Kecamatan Omben maupun Kecamatan Proppo.Sehingga masyarakat mendapatkan hasil yang tidak begitu maksimal dari hasil bertani singkong.

2. Penyuluhan Atau Ceramah

penyuluhan atau ceramah dalam hal ini bermasud untuk memberi informasi terkait beberapa hal atau kegiatan yang akan dilakukan serta memberikan gambaran dan wawasan mengenai langkah yang akan dilakukan dalam pengembangan produk unggulan desa.

3. Focused Group Discussion (FGD)

Focused Group Discussion(FGD), dilakukan guna mendapatkan informasi terkait problem dan strategi guna mendapatkan meningkatkan produktivitas produk unggulan yang ada di desa.Dalam FGD ini turut dihadirkan tokoh masyarakat, kelompok tani, kelompok usaha desa/BUMDesa, Pemerintah Desa dan BPD. Dalam proses preliminary survey, tim pengabdian mencari tahu mengenai kondisi awal, baik dari sisi potensi maupun tantangan yang terdapat di tengah-tengah masyarakat yang berkaitan dengan pengembangan Produk Unggulan Desa ini. Preliminary survey ini terbagi menjadi 2 sub-kegiatan.Sub-kegiatan pertama yaitu berkunjung ke 
Kantor Desa dan bertemu dengan perangkat desa. Kemudian, sub-kegiatan kedua adalah tim pengabdian berkunjung ke beberapa lokasi rumah yang memiliki usaha dan melakukan interview singkat terhadap pengelola yang ada. Proses selanjutnya adalah dilakukan rangkaian kegiatan berupa penyuluhan dan FGD Kantor Desa Madulang, Kecamatan Omben, Kabupaten Sampang. Kegiatan berupa penyuluhan ini bertema Sosialisasi Pengembangan Produk Unggulan Perdesaan (Prukades).FGD menjadi kegiatan selanjutnya, dimana melalui forum ini bisa didapatkan gambaran secara lebih mendetail kondisi riil yang ditemui oleh masyarakat desa.FGD ini terbagi menjadi 3 kelompok, yaitu kelompok tani singkong, kelompok pelaku usaha kripik Tette, dan kelompok pemuda penggiat pemasaran online.Selanjutnya, kegiatan berupa konsultasi yang bertujuan untuk memberikan kesempatan kepada masyarakat dalam menyampaikan hambatan, tantangan, maupun kendala saat melakukan tindak lanjut dari pengembangan Prukades ini, sehingga diharapkan mendapat solusi yang proporsional. Konsultasi ini dilakukan dengan media interaksi berupa sms/whatsapp, telepon ataupun media lainnya dari masyarakat dengan tim pengabdi. Melalui proses konsultasi ini pula, tahap evaluasi kegiatan bisa sekaligus dilaksanakan.

\section{Pengembangan Prukades Melalui Growth Hacking Strategy Di Kecamatan Omben}

Perkembangan Prukades di Kecamatan Omben cukup signifikan, namun masih belum begitu optimal dalam pengelolaannya. Umumnya komoditas unggulan yang ada di setiap desa kecamatan omben masih seputar padi dan jagung, hal ini dapat dilihat pada table berikut ini:

Tabel 3 Komuditas Unggulan Kec. Omben

\begin{tabular}{|c|c|c|c|}
\hline \multirow[b]{2}{*}{ No } & \multirow[b]{2}{*}{ DESA } & \multicolumn{2}{|c|}{ PRODUK UNGGULAN DESA } \\
\hline & & $\begin{array}{l}\text { KOMODITAS } \\
\text { PANGAN }\end{array}$ & $\begin{array}{c}\text { KOMODITAS NON } \\
\text { PANGAN }\end{array}$ \\
\hline 1 & Kebun Sareh & Padi & Air Isi Ulang \\
\hline 2 & Karang Nangger & Padi, Jagung & Tusuk Sate \\
\hline 3 & Rapa Laok & Kelapa & \\
\hline 4 & Rapa Daya & Padi, Jagung & \\
\hline 5 & Astapah & Padi, Jagung & Sandal \\
\hline 6 & Sogian & Padi, Jagung & \\
\hline 7 & Gersempal & Padi, Jagung & \\
\hline 8 & Temoran & Sukun & \\
\hline 9 & Meteng & Padi & Bambu \\
\hline 10 & Madulang & Singkong & \\
\hline 11 & Kamondung & Padi & \\
\hline 12 & Omben & Padi & Sumber Air \\
\hline 13 & Tambak & Padi & \\
\hline 14 & Angsokah & Gula Aren & \\
\hline 15 & Jrangoan & Padi & \\
\hline 16 & Rongdalam & Gula Aren & \\
\hline 17 & Napo Laok & $\begin{array}{l}\text { Padi, Kelapa, } \\
\text { Air }\end{array}$ & Wisata religi \\
\hline 18 & NapoDaya & Padi, Jagung & \\
\hline 19 & Karang Gayam & Rambutan & \\
\hline 20 & Pandan & Mente & \\
\hline
\end{tabular}


Pada tabel diatas menunjukkan produk unggulan di beberapa desa di Kecamatan Omben Kabupaten Sampang masih relative sama, masih banyak yang bergantung pada produk musiman antara lain padi dan jagung. Dalam perkembangannya komoditas yang dihasilkan tersebut masih tergolong sedikit yang megelolanya. Disisi lain terdapat beberapa komoditas non pangan yang mulai tumbuh, hal ini didasari pada pengembangan desa lewat sisi BUMDes.

Pembangunan yang berkelanjutan menjadi pedoman utama guna menjaga ekosistem agar sumberdaya alam terus menerus dapat dirasakan oleh anak cucu dimasa mendatang. Pembangunan berkelanjutan bertujuan untuk meningkatkan kesejahteraan manusia dengan mengembangkan dan memanfaatkan SDA yang ada. Dalam pemanfaatan SDA melalui pembangunan senantiasa terjadi perubahan ekosistem yang pada akhirnya memberi dampak positif (manfaat) ataupun dampak negatif (resiko) terhadap manusia kembali.

Pada table diatas dari sekian desa yang memiliki produk unggulan desa baik pangan ataupun non pangan, ternyata masih sedikit pula desa yang mengembangkan hasil komoditinya. Dari 20 desa di Kecamatan Omben Desa Madulang merupakan salah satu desa yang sangat aktif dalam mengelola produk unggulan desanya.

Keberadaan sumber daya yang baik, belum mampu medatangkan hasil pertumbuhan ekonomi yang signifikan. Hal ini dari sisi pengelolaannya masih sedikit sekali desa yang mengelolanya. Desa Madulang merupakan salah satu desa yang sudah melakukan terobosan guna mengelola produk unggulan desanya agar memberikan dampak yang positif terhadap peningkatan perekonomian di desanya.

1. Akuisisi Produk

Terdapat lima elemen yang ada pada growth hacking salah satunya akuisisi. Produk unggulan Desa Madulang ini sudah difasilitasi untuk membuatk akun di beberapa media social, sehingga dalam hal ini memungkinkan agar tidak hanya mendapatkan pelanggan di dunia offline saja, melainkan secara online. Akun tersebut berupa akun Instagram, Wa, dan FB.

Penguasaan pasar lewat media online, menjadi jalur alternatif untuk memenangkan promosi produk dan meningkatkan jumlah pemasaran. Pada kondisi pendemi saat ini, dimana pemerintah menerapkan kebijakan Social Distancing dan 
Physical Distancing, membuat semua produk mengalami kemerosotan. Namun hal ini tidak berpengaruh pada pemasaran lewat online.

Pemasaran online yang lebih dikenal dengan istilah e-commerce adalah istilah yang menggambarkan penjualan barang dan jasa melalui internet. Pemasaran melalui media internet memungkinkan suatu usaha untuk menjalankan praktek self-service. Hal ini berarti suatu usaha dapat memberikan pelayanan kepada pelanggan tanpa membutuhkan tenaga SDM, mengurangi fasilitas dan layanan melalui telepon.

Ketua Asosiasi Kepala Desa Se-Kecamatan Omben Kabupaten Sampang. Dari hasil wawancara berharap besar agar semua desa dapat menemukan potensi-potensi unggulan yang daoat dikembangkan di desanya. Ketua AKD Kecamatan Omben juga telah memberikan apresiasi yang besar terhadap Desa Madulang yang sudah mengelola dan mengembangkan produk unggulan desa dengan baik. Namun seiring dengan perkembangan teknologi model perilaku masyarakat kini mulai bergeser pada gadget, sehingga setiap pengguna atau masyarakat banyak beralih pada layanan media termasuk perbelanjaan, sehingga produk unggulan desa madulang harus menguasai pemasaran di media online.

\section{Activation}

Strategy Activation dilakukan apabila produk unggulan desa sudah mendapat pelanggan atau sudah menjadi camilan favorite di hati pelanggan. Dalam penerapannya, Kripik Tette Madulang yang merupakan Produk Unggulan Desa Madulang, sudah menjadi makanan khas masyarakat Madura. Dan sudah menjadi camilan yang wajib ada di setiap rumah warga. Hal ini dikarenakan kripik Tette yang sangat mudah di temui dengan karakteristik yang gurih renyah ditambah dengan sambah petis sudah menjadi bagian dari tradisi masyarakat Madura.Sehingga dalam hal ini pada konsepnya produk unggulan Desa Madulang ini sudah mendapatkan posisi yang baik dihati pelanggan. Namun pada teknik Activiation ini sangat perlu dilakukan dalam pengembangan pemasaran produknya, hal ini berkaitan dengan jumlah produksi yang nantinya akan dicapai.

Dalam penerapannya, para pelanggan produk unggulan desa Kripik tette madulang digiring untuk dimasukkan kedalam situs khusus produk unggulan desa agar pelanggan mengetahui secara gamblang apa saja produk unggulan yang ditawarkan, dan bagaimana para pelanggan mampu di edukasi lewat video-video proses pengolahan 
produk unggulan desa tersebut.asumsinya ketika pelanggan atau masyarakat luas sudah digiring untuk melihat pada web atau aplikasi yang sengaja dibuat untuk lebih mengedukasi pelanggan, maka harapannya pelanggan akan tertarik pada produk unggulan yang dijual dan semakin memperluas jaringan pemasaran terhadap masyarakat sekitar. Hal ini senada dengan penyampaian informan 8 .

"layanan khusus seperti website, blog ataupun lainnya yang mengedukasi tentang suatu produk unggulan Desa khususnya produk kripik tette madulang, memberikan wawasan tersendiri terhadap para pelanggan untuk mengetahui secara gambling dan lebih menyakinkan pelanggan agar tetap mengkonsumsi produk unggulan desa madulang tersebut." (Noval Akbar, Tim Pemasaran Produk Kecamatan Omben Kab. Sampang, In-depth Interview tanggal 22 Juli 2020).

Kecanggihan teknologi menuntut setiap masyarakat perlu beradaptasi dengannya termasuk teknik pemasaran produk. Apabila produk unggulan desa masih berputar-putar dengan teknik offline, maka hal ini lambat laun akan kehilangan pelanggan, alhasil, usaha akan bangkrut dalam jangka panjang. Teknologi pencari masa kini telah menggunakan sistem semantic search yang lebih baik dibandingkan cara lama karena semua hal kini hanya ditentukan oleh input kata kunci (keywords). Mesin pencari seperti Google misalnya, mencoba membuat pencarian lebih berorientasi pada konsumen dengan menampilkan hasil pencarian berdasarkan keinginan pengguna. Oleh karena itu keberadaan Website guna menggiring pelanggan masuk kedalam media online yang kita kelola maka kesempatan untuk memasarkan produk kita lebih baik.

Mujalli sebagai pendamping professional Kecamatan Omben Kabupaten Sampang melihat peluang bahwa kebutuhan teknologi dimata masayarakat sudah tidak mengenal usia, dari yang muda sampai yang tua semua berbondong- bonding beralih pada gadget yang dimiliki. Sehingga tak hayal jika pergesaran pasar kini sudah banyak ke social media. Ini merupakan kesempatan baik untuk mempromosikan produk unggulan Desa Madulang, mengingat masayarakat sudah banyak yang tau tentang produk unggulan Desa Madulang, serta produk tersebut sudah mendapatkan posisi yang baik di kalangan pecinta kuliner Madura. Sehingga langkah selanjutnya tinggal bagaimana tim pemasaran mempoles lewat website atau media online untuk dapat menggaet pelanggan sebanyak-banyaknya. 
Kecanggihan teknologi sudah tidak dapat dipungkiri, kondisi siapa yang dapat lambat akan tertinggal dengan mereka yang cepat. Kecepatan-kecepatan informasi inilah yang harusnya kita optimalkan agar tidak ketinggalan jaman seiring kecanggihan teknologi dan informasi. Kecanggihan teknologi tidak beregantung pada batas usia. Kini anak muda bahkan anak balita sudah pintar memainkan kecanggihan gadget yang ada di smartpon masing-masing. Hal demikian menunjukkan bahwa sebagai orang dewasa hendaknya lebih cerdas dan lebih mampu menggunakan teknologi agar dapat mengotrol anak-anak kita.

\section{Retention}

Strategi Retention dapat dikembangkan melalui notifikasi-notifikasi khusus yang dibuat agar pelanggan teredukasi serta menjadi pengingat/alarm akan produk unggulan desa ini. Melalui promosi-promosi di akun SMS, Youtube, Instagram, Story WA, dan di berbagai took online lainnya, menjadikan tanda-tanda khusus bagi setiap pelanggan untuk kembali mengkonsumsi produk unggulan desa tersebut.

Biasanya notifikasi-notifikasi tersebut sangat bermanfaat dan memperoleh keuntungan besar apabila menjelang bulan puas, lebaran, mantenan dan acara-acara besar lainnya, hal ini dimungkinkan menjadi camilan alternatif untuk disuguhkan kepada tamu-tamu yang berkunjung.

Dari hasil wawancara dengan Kepala Desa Menyebutkan bahwa strategiRetention yang dilakukan cukup baik untuk mengingatkan pelanggan agar melakukan pembelian terhadap produk unggulan Desa Madulang.Ketika notifikasinotifikasi tidak dilakukan, dan system pemasaran harnya bersifat monoton cendrung pembelian produk unggulan desa masih minim. Namun saat strategiRetention di lakukan, baik lewat SMS, media insta story, story WA, FB dan lain-lain, pelanggan seringkali benayak merespon dengan baik bahkan banyak melakukan pembelianpembelian produk secara besar-besaran. Hal ini sesuai dengan hasil wawancara mendalam dengan informan:

“terus terang saya melihat bahwa masayarakat melakukan pembelian produk unggulan desa secara besar-besaran disaat menjelang bulan puasa, lebaran, pesta acara pernikahan dan acara-acara kegamaan lainnya. Hal ini disebabkan banyaknya perantua yang akan pulang kekampung halamannya dan pasti mereka akan disuguhi dengan makanan/camilan khas produk unggulan desa Madulang yaitu Kripik Tette, 
selain itu saaat mereka kembali kekampung halamannya mereka pula justru membeli produk unggulan tersebut untuk dibawa ketempat perantaun sembari memperkenalkan produk tersebut ke masyarakat luar. Hal ini sangat baik sekalidan tak lepas dari strategy activation yang dilakukan." (Informan 12Ijasi Ketua BUMDesa Madulang Jaya, In-depth Interview tanggal 28Juli 2020).

Dari hasil wawancara mendalam dengan ketua BUMDesa Madulang Jaya, yang telah memproduksi produk unggulan Kripik Tette Khas Madulang, menyatakan bahwa strategi Retention pelanggan produk unggulan desa sangat berpengaruh besar terhadap tingkat pembelian produk unguulan desa, hal ini dimungkinkan bahwa masyarakat desa yang datang dari tempat perantau ataupun yang akan kembali ke tempat perantuan turut mendominasi tingkat pembelian produk unggulan yang ada di Desa Madulang. Hal ini dikarenakan adanya layanan informasi dan promosi yang dilakukan oleh pihak pemerintah desa ataupun produsen produk unggulan desa melalui berbagai media.

\section{Revenue}

Tahapan revenue merupakan tahapan diamana para pelanggan sudah mampu memberikan efek positif terhadap pendapatan dari hasil penjualan produk unggulan desa tersebut. Hal ini menunjukkan bahwa tahapan diatas sudah dapat dilakukan dengan baik dan sesuai dengan pedoman yang dianjurkan. Pada posisi ini semua pelanggan produk unggulan Desa Madulang Kripik Tette sudah tetap. Artinya jumlah permintaan produk sudah berkisar diambang batas produksi, sehingga hal ini sangat mudah dihitung prosentase hasil dari setiap produksi yang dihasilkan.

Namun pada tahapan saat ini, produk unggulan Desa Madulang Kripik Tette masih berada di tahapan retentation, sehingga proses demi proses tetap dilaksanakan, hal ini memungkin agar produk unggulan kripik Tette desa madulang dapat mencapai hasil yang maksimal. Seiring dengan Growth Hacking Strategy yang dilakukan, produk unggulan kripik tette Desa Madulang sudah mulai menemukan ritme penjual yang cukup baik, hal ini dapat kita lihat pada table dibawah ini:

Tabel 4. Total Produksi per Tahun

\begin{tabular}{|c|c|c|c|}
\hline \multirow{2}{*}{ BULAN } & \multicolumn{3}{|c|}{ TOTAL PRODUKSI BKS/TAHUN } \\
\cline { 2 - 4 } & $\mathbf{2 0 1 8}$ & $\mathbf{2 0 1 9}$ & $\mathbf{2 0 2 0}$ \\
\hline 1 & 50 & 115 & 235 \\
\hline 2 & 63 & 125 & 250 \\
\hline 3 & 78 & 157 & 275 \\
\hline 4 & 100 & 357 & 457 \\
\hline 5 & 130 & 300 & 432 \\
\hline 6 & 125 & 315 & 400 \\
\hline 7 & 270 & 357 & 425 \\
\hline 8 & 152 & 312 & 525 \\
\hline 9 & 200 & 280 & 500 \\
\hline 10 & 176 & 275 & 513 \\
\hline 11 & 275 & 315 & \\
\hline 12 & 160 & 375 & \\
\hline TOTAL & 1,779 & 3,283 & 4,012 \\
\hline Data $:$ BUMDesa Madulang Jaya & & \\
\multicolumn{5}{|c}{} \\
\hline
\end{tabular}


Dari data table diatas menunjukkan tren yang positif dari produksi produk ungula kripik tette Desa Madulang setiap setiap tahunnya, pada tahun 2018, jumlah produksi yang dikeluarka sebesar 1.779 bungkus Kripik yang terjual habis, sedang pada tahun 2019 meningkat tajam hampir 2 kali lipat dari sebelumnya, sedangkan pada tahun 2020 peningkatan produksi juga terjadi namun tidak begitu signifikan dibanding tahun 2019. hal ini diasumsikan bahwa dampak covid-19 sangat berpengaruh besar terhadap permintaan produk unggulan Kripik Tette Desa Madulang.

Sektor Usaha Mikro Kecil dan Menengah (UMKM) menghadapi sejumlah persoalan di masa pandemi covid-19. Salah satunya, penurunan angka penjualan. Tak sedikit UMKM yang harus tutup usaha akibat dari dampak covid-19.Pemberlakuan kebijakan PSBB membuat sejumlah aktivitas perekonomian lumpuh.

Adanya dampak Covid-19 membuat sistem perbelanjaan juga mangkrak, namun ada satu hal dari sisi perekonomian yang belum surut, yakni pembelanjaan lewat media online. Peranan media online sungguh sangatberdampak besar sekali disaat pandemil, hal ini membuat semua sektor beralih pada media online. Termasuk perbelanjaan. Banyak pelanggan Produk Unggulan Kripik Tette Desa Madulang yang beralih pada sistem online. Berikut hasil wawancara dengan salah satu informan 16.

"saya merasa senang sekali ketika semua kebutuhan saya masih bisa terpenuhi walau dalam kondisi pandemi. Kehadiran pelayanan Produk Unggulan Kripik Tette Desa Madulang lewat online." (Informan 16Iin Safiyatun Pelanggan Online Luar Daerah, In-depth Interview tanggal 30 Juli2020).

Kondisi seperti ini memang sangat berat untuk dilalui, namun setiap hasil tidak akan mengingkari usaha yang dilakukan. Oleh karena itu perjalanan berat untuk mengembangkan usaha produk unggulan desa sangat berat untuk dilalui.Banyak pelanggan yang awalnya sudah berpaling dan banyak yang menghentikan pesenannya, namun seiring pengembangan model pemasaran di media online kini produk unggulan kripik tette Desa Madulang masih mampu beroperasi dengan baik, walau perkembangannya masih belum signifikan.

\section{Referral}

Tahapan ini adalah bagaimana pengguna dapat mengundang teman-teman mereka untuk bergabung. Dalam tahapan ini seperti menumbuhkan loyalitas pengguna 
untuk menarik pengguna baru. Beberapa cara seperti memberi tawaran khusus dengan insentif atau hadiah jika mengundang pengguna baru.

Produk unggulan Kripik Tette Desa Madulang kini sudah mendapatkan tempat untuk para pelanggannya.Pelanggan yang tidak hanya di area Madura melainkan daerah jawa dan luar daerah lainnya kini terus bertambah akibat dari pemasaran yang dilakukan dari berbagai media online.Pelanggan inilah kini yang menjadi promotor dari produk unggulan Kripik Tette itu sendiri di wilayah mereka berada

Jadi tak sedikit dari para pelanggan yang biasa membeli produk Unggulan Kripik Tette madulang yang kini turut ikut memasarkan produk tersebut lewat komunikasi yang dijalin baik atar WA, Group, Kelompok dan Lain-lain. Disisi lain pemasaran lewat jaringan antar kepala desa, antar instansi pemerintah kabupaten dan lain-lain turut dioptimalkan. Hal ini mengingat pengembangan produk unggulan desa merupakan salah satu model pemberdayaan yang harus dilakukan untuk meningkatkan perekonomian di desa.

Sehingga semua elemen dan semua instansi mempunyai tanggung jawab besar untuk terus mengembangkan dan membangkitkan produk unggulan desa tersebut.

Jaringan kepala desa di seluruh desa yang ada di Kecamatan Omben turut bahubahu ikut membantu setiap proses pengembangan produk unggulan yang ada di desadesa di kecamatan omben. Lewat persatuan antar kepala desa, kini beban tim pemasaran Produk Unggulan Kripik Tette madulang tidak begitu berat. Karena setiap pemerintah desa se-Kecamatan Omben turut membeli dan ikut memasrkan produk tersebut. Hal ini selain karena produk tersebut sangat mudah untuk dikenal dan dijumpai juga produk unggulan tersebut dikemas semenarik mungkin sehingga memberika kesan yang elegan untuk turut di pasarkan ke semua warga.

Dari sekian banyak masayarakat desa yang turut menjadi pelanggan Produk Unggulan kripik tette ini, mereka juga ikut membantu mengajak teman-temannya untuk ikut membeli produk tersebut.Hal ini dikarenakan produk unggulan tersebut sudah tidak asing lagi bagi masayarakat Madura, dan produk itu juga telah menjadi bagian dari camilan yang wajib bagi masyarakat Madura untuk terus dikembangkan.

\section{Strategi Pengembangan Produk Unggulan Kripik Tette Desa Madulang}

Pengembangan Produk unggulan Kripik Tette Desa Madulang melalui Growth Hacking Strategy ditemukan sebuah beberapa potensi dan permasalahan yang 
menggerucut pada titik kondisi dimana produk tersebut belum melakukan pengembangan pemasaran secara meluas melalui social media, sehingga hal ini perlu diberikan pelatihan dan pembinaan oleh peneliti agar dapat menghasilkan sebuah tools/alat yang berguna untuk meningkatkan pendapatan dan peningkatan jumlah produksi produk unggulan tersebut.oleh karena itu, seiring pengembangan produk unggulan melalui growt hacking strategy, juga digunakan metode analisis SWOT agar tim peneliti mengetahui beberap kriteria terkait kekuatan, kelemahan, ancaman dan peluang dalam pengembangan produk unggulan tersebut. Berikut Tabel SWOT produk unggulan Kripik Tette Desa Madulang sebagaimana dibawah ini:

\section{KESIMPULAN}

Dari hasil dan pembahasan yang sudah di paparkan diatas, dapat ditarik kesimpulan bahwa pada dasarnya pengembangan Produk Unggulan Kripik Tette Desa Madulang Khas Madura ini sudah mendapatkan posisi yang layak di hati para pelanggannya.Hal ini dapat dibuktikan dari sekian banyak pelanggan yang sudah membeli produk tersebut baik lewat online maupun offline. Perkembangan hasil produksi pada tahun 2018 sampai dengan tahun 2019 menghasilkan niai yang cukup signifikan perkembangannya, hal ini disebabkan masyarakat sudah mulai tau tentang produk yang dihasilkan oleh Desa Madulang.

Di awal tahun 2020, Banyak UMKM yang merosot dihantam oleh pandemi adanya virus covid-19 termasuk produk unggulan Desayang sempat merosot.Namun seiring dengan strategi yang dilakukan melalui pembinaan dan pendampingan secara massif lewat Growth Hacking Strategycukup membuahkan hasil yang baik untuk meningkatkan pendapatan di masa pandemik. Walaupun pertumbuhannya tidak begitu maksimal, namun perkembangan produksi produk unggulan Desa Madulang tetap mengalami peningkatan.

Growth Hacking Strategy tersebut cukup ampuh untuk diterapkan bagi pelaku usaha awal yang ingin memenangkan pemasaran baik secara online maupun offline.Walaupun masih pemula Produk Unggulan Kripik Tette Madulang sudah mampu bersaing dengan produk-produk lainnya, minimal tidak merosot di masa pandemi sudah merupakan keajaiban yang luar biasa bagi sekelas produk awal kripik tette madulang khas madura. 


\section{REKOMENDASI}

a. Dalam penelitian selanjutnya harus lebih fokus pada teknis strategi pemasaran lewat online, atau penguasaan di berbagai media sosial

b. Lebih banyak model pengembangan yang dilakukan.

\section{UCAPAN TERIMAKASIH}

Penelitian ini merupakan penelitian yag dilakukan dengan maksud dan harapan dapat membantu mengembangkan produk unggulan desa berupa kripik tette khas madulang yang start up agar dapat berkembang lebih baik lagi, peneliti mengucapkan banyak terimakasih dan apresiasi yang luar biasa sekali kepada kementrian riset dikti yang telah memberikan support dana penelitian agar dapat terlaksana kegiatan penelitian ini dengan baik.

selanjutnya kami juga ucapkan banyak terimkasih kepada seluruh pihak yang telah membantu dalam penyusunan data dan dokumen semoga amal dan niat baik kita diganjar oleh Allah SWT. Amin Allahumma amin.

\section{DAFTAR PUSTAKA}

\section{Buku}

Abdullah, Thamrin \& Tantri, Francis.(2015). Manajemen Pemasaran. Jakarta: Raja GrafindoPersada.

Ali Hasan, 2013, Marketing, Cetakan Pertama, Media Pressdindo Yogyakarta.

Ellis, Sean \& Brown, Morgan (2017), "Srategies For Hacking Growth", Customer RelationshipManagement.

Mullins, John W dan Walker Jr, Orville C. 2013.Marketing Management: A Strategic Decision-Making Approach, 8th Edition, McGraw-Hill International Edition.

Strauss, Anselm \& Corbin Juliet (2015), "Dasar-dasar penelitian kualitatif”, Yogyakarta : Pustaka Pelajar.

\section{Jurnal}

Dewi J.M, Joko W dan Sutrisno Djaja. 2019 "Strategi Pemasaran Usaha Mikro, Kecil dan Menengah (UMKM) Batik Magenda Tamanana Kabupaten Bondowoso". Jurnal Pendidikan Ekonomi Volume 13 Nomor 1

Hartono, Hendry, dkk. 2012. Pengaruh Strategi Pemasaran Terhadap Peningkatan Penjualan Pada Perusahaan" Dengan Menetapkan Alumni dan Mahasiswa Universitas Bina Nusantara Sebagai Objek Penelitian. Jurusan Manajemen. Universitas Bina Nusantara. Jakarta Barat.Jurnal (Online).

McLean, J, Graeme (2017), "Investigating The Online Customer Experience - a B2B Perspective”, Marketing Intelligence \& Planing, vol. 35, no. 5, pp. 657-672.

Singh, Jaywant, Kalafatis, P, Stavros \& Ledden, Lesley (2014), "Consumer Perception of Cobrands : The Role of Brand Positioning Strategies", Marketing Intellingence \& Planning, vol. 32, no. 2, pp. 145-159.

Shaltoni, Monim, Abdel (2017), "From Website to Social Media :Exploring The Adaption of Internet Marketing in Emerging Industrial Markets", Journaal of Business \& Industrial Marketing, vol. 32, no. 7, pp. 1009-1019. 
Tambajong, Geraldy. 2013. Bauran Pemasaran Pengaruhnya Terhadap Penjualan Sepeda Motor Yamaha Di Pt. Sarana Niaga Megah Kerta Manado. Jurnal EMBA Volume 1 Nomor 3 September 2013.

Weinstein, Art (2014), “Target Market Selection in B2B Technology Markets", Journal of Marketing Analytics, vol. 2, no. 1, pp. 59-69.

$\mathrm{Fu}, \mathrm{Q}$, Frank \& Elliott, T, Michael (2013), "The Moderating Effect of Perceived Product Innovativeness and Product Knowlage on New Product Adoption : An Integrated Model", Journal of Marketing Theory and Practice, vol. 21, no. 3, pp. 257-272. 